\title{
LORAZEPAM AND DIAZEPAM AS ADJUNCTS TO EPIDURAL ANAESTHESIA FOR CAESAREAN SECTION
}

\author{
B.Y. Ong, B.G. Pickering, R.J. Palahniuk and M. Cumming
}

\begin{abstract}
Lorazepam $0.05 \mathrm{mg} \cdot \mathrm{kg}^{-1}$ and diazepam $0.1 \mathrm{mg} \cdot \mathrm{kg}^{-1}$ administered intravenously were compared as sedatives for 42 patients undergoing Caesarean Section under epidural anaesthesia. After receiving the drug, 15 per cent of the diazepam patients and 32 per cent of the lorazepam patients were still agitated. Ten per cent of the diazepam patients and 36 per cent of the lorazepam patients had severe symptoms of delirium. These included hallucinations, confusion, agitation, restlessness, inappropriate weeping and repetitive hand movements. Memory impairment was greater with lorazepam. Thirty-five per cent of the diazepam patients had pain at the injection site. None of the lorazepam patients had such pain. Respiratory rate, heart rate and mean blood pressure did not change significantly in either group. Half the patients who had been given lorazepam had side effects that were bothersome enough to cause them to complain the following day. Lorazepam and diazepam were both unsatisfactory as sedatives for patients having Caesarean Section.
\end{abstract}

KEY WoRDS: HyPNotics, diazepam, lorazepam; ANAEsthesia, obstetrical; ANaESThetic TeChniques, epidural; Surgery, Caesarean Section.

ANXIETY is a common problem in patients undergoing Caesarean Section with regional anaesthesia. This may be related to the operating room atmosphere, the surgical procedure and the concern about the baby. Many patients therefore receive some form of sedation after delivery of the baby. We undertook to compare the effects of two benzodiazepines, diazepam and lorazepam, as intravenous sedation for these patients.

Diazepam has been a commonly used agent in our institution, but clinical impression of a high incidence of unwanted side effects and failures led us to seek a better agent. Lorazepam has been used successfully as an adjunct to regional anaesthesia in other situations. ${ }^{1}$ In patients exhibiting symptoms of anxiety lorazepam was more effective than diazepam. ${ }^{2,3}$ When the drugs

B.Y. Ong, M.D., B.Sc.(Med), F.R.C.P.(C), Assistant Professor; B.G. Pickering, M.D., F.R.C.P.(c), Lecturer; R.J. Palahniuk, M.D., F.R.C.P.(c), Professor and Chairman; M. Cumming, R.N., B.Sc., Research Assistant, Department of Anaesthesia, Health Sciences Centre, University of Manitoba, Winnipeg, Manitoba.

This work was supported by a grant from Wyeth Limited.

Reprint requests to: Dr. B.Y. Ong, Department of Anaesthesia, University of Manitoba, Health Sciences Centre-General, 700 William Avenue, Winnipeg, Manitoba R3E 0Z3.

Can. Anaesth. Soc. J., vol, 29, no. 1, January 1982 were compared as premedicants, more restlessness and dizziness were observed in patients who had received diazepam. ${ }^{4}$ Lorazepam did not cause any significant change in cardiovascular or respiratory parameters. ${ }^{5}$

The protocol was approved by the faculty committee on the use of human subjects on research. All patients consented to take part in the study. Forty-two patients having elective Caesarean Sections under epidural anaesthesia were randomly assigned to receive either diazepam or lorazepam. No placebo group was included because it was felt inappropriate to deny sedation to any patient in need of it. The patients were given no premedication. Lumbar epidural anaesthesia was established in the usual manner and a block sufficient to produce analgesia was achieved using $18-20 \mathrm{ml}$ of carbonated lidocaine with epinephrine $1 / 200,000$. Any patient with incomplete analgesia was excluded from the study and managed appropriately. After delivery of the infant, twenty-two patients received lorazepam $0.05 \mathrm{mg} \cdot \mathrm{kg}^{-1}$ intravenously (lorazepam patients) and twenty patients received diazepam $0.1 \mathrm{mg} \cdot \mathrm{kg}^{-1}$ intravenously (diazepam patients). The identity of the medication injected by one of the investigators was concealed from the patient, the attending anaesthetist and the nurse observer. The observer for 
all the patients was a nurse with five years' experience in interviewing obstetrical patients post-operatively about anxiety, pain and anaesthetic effects.

The observer, based on her observations, rated each patient's level of anxiety and degree of sedation before drug administration, and at five, fifteen and thirty minutes after, according to the categories listed in Table I. At the same times, the patient's blood pressure, heart rate, respiratory rate and any side effects were observed and recorded. Similar assessments were done on arrival in the recovery room, and fifteen, thirty and forty-five minutes later.

To test memory, different pictures of common objects were shown to the patient at five, fifteen and thirty minutes after drug administration as well as fifteen minutes after arrival in the recovery room; thus four pictures were shown to each patient. Twenty-four hours later the patients were questioned to determine if they could recall or recognize the picture cards shown and various events that occurred during the perioperative period.

Statistical analyses for age, weight, mean blood pressure, heart rate and respiratory rate of the two groups were done using unpaired Student's t-test. A Chi-square test was used for comparison of the level of anxiety, degree of sedation, impaired recall, and incidence of side effects among the two groups of patients. A probability of $P<.05$ was considered statistically significant.

\section{Results}

The two groups of patients did not differ significantly in age or weight (Table II).

The respiratory rates, heart rates and mean blood pressures for the two groups did not differ significantly at 15 minutes after administration of the drug (Table III).

Before administration of the sedatives, 25 per cent of the diazepam patients and 27 per cent of the lorazepam patients were judged to be agitated. After drug administration, the corresponding values were 15 and 32 per cent. The differences were statistically not significant.

After drug administration, 50 per cent of the diazepam patients and 59 per cent of the lorazepam patients fell asleep. Usually, the sleep lasted only a few minutes and all could be roused by voice except for one patient in each group who only reacted to touch.

Ninety-one per cent of the lorazepam patients
TABLE I

Assessment of AnXIETy and Sedation

\begin{tabular}{ll}
\hline \hline & \multicolumn{1}{c}{ Anxiety } \\
A & fully relaxed \\
B & mildly agitated \\
C & moderately agitated \\
D & severely agitated \\
& $\quad$ Sedation \\
A & awake, responds to questions \\
B & awake, does not respond to questions \\
C & asleep, rouses to voice \\
D & asleep, rouses to touch \\
D & asleep, rousable with difficulty or not at all
\end{tabular}

TABLE II

Age and Weight of Patients

\begin{tabular}{lcc}
\hline \hline & $\begin{array}{c}\text { Lorazepam } \\
\text { Patients }\end{array}$ & $\begin{array}{c}\text { Diazepam } \\
\text { Patients }\end{array}$ \\
\hline Age (years \pm S.D.) & $27.6 \pm 5.2$ & $27.2 \pm 5.0$ \\
Weight (kg \pm S.D.) & $75.5 \pm 12.7$ & $75.7 \pm 11.9$ \\
\hline
\end{tabular}

and 50 per cent of the diazepam patients had difficulty in recalling at least one event that occurred after drug administration. All patients had good recall of events that occurred before drug administration. The percentages of patients in each group with impaired recall of the different memory cards shown are listed in Table IV.

A large number of patients experienced side effects (Table V). Eight (36 per cent) of the lorazepam patients and two (10 per cent) of the diazepam patients had symptoms of delirium. These were severe and included hallucinations, confusion, agitation, restlessness, inappropriate weeping and repetitive hand movements. Although the patients did not recall these symptoms, one patient was extremely unhappy about the experience. During the post-operative visit she told the nurse that the day of the operation was the worst day in her life and remembered seeing pictures that had not been shown to her. Of the other patients who received lorazepam, two complained about excessive drowsiness and memory impairment, while three others had diplopia. In total, eleven of the twenty-two lorazepam patients had either symptoms of delirium or side effects that were bothersome enough to cause them to complain the following day.

Thirty-five per cent of the diazepam patients 
TABLE III

\begin{tabular}{lcc}
$\begin{array}{c}\text { Mean Blood Pressure, Heart Rate and Respiratory Rate } \\
\text { After Drug Adinistration }\end{array}$ & $\begin{array}{c}\text { Lorazepam } \\
\text { Patients }\end{array}$ & $\begin{array}{c}\text { Diazepam } \\
\text { Patients }\end{array}$ \\
\hline \hline & $11.2 \pm 1.5$ & $11.0 \pm 1.4$ \\
\hline Mean blood pressure (kPa \pm S.D.) & $94.6 \pm 16.1$ & $99.4 \pm 17.2$ \\
Heart rate (beats/min \pm S.D.) & $18.2 \pm 2.9$ & $18.2 \pm 3.0$ \\
Respiratory rate (breaths/min \pm S.D.) & 2.9 \\
\hline
\end{tabular}

TABLE IV

Percentage of Patients with Impaired Recall

\begin{tabular}{lcc}
\hline \multicolumn{1}{c}{ Impaired recall of } & $\begin{array}{c}\text { Lorazepam } \\
\text { Patients } \\
\text { (per cent) }\end{array}$ & $\begin{array}{c}\text { Diazepam } \\
\text { Patients } \\
\text { (per cent) }\end{array}$ \\
\hline at least one of the cards shown & 91 & 50 \\
card shown 5 minutes after drug injection & 41 & 35 \\
card shown 15 minutes after drug injection & 68 & 50 \\
card shown 30 minutes after drug injection & 91 & $25^{*}$ \\
card shown 15 minutes after arrival in recovery room & 91 & $40^{*}$ \\
\hline$* P<0.05$ & &
\end{tabular}

TABLE V

Number of PATIENTS WITH Side EFFEcts

\begin{tabular}{lcc}
\hline \hline & $\begin{array}{c}\text { Lorazepam } \\
\text { Patients }\end{array}$ & $\begin{array}{c}\text { Diazepam } \\
\text { Patients }\end{array}$ \\
\hline Total number of patients & 22 & 20 \\
delinium & $8^{*}$ & 2 \\
diplopia & 3 & 1 \\
nausea & 0 & 2 \\
pain on injection & $0^{*}$ & 7 \\
\hline
\end{tabular}

$* \mathrm{P}<0.05$

had pain at the injection site. None of the lorazepam patients had such pain.

\section{Discussion}

In our study, lorazepam was associated with a high incidence of mental aberrations. Previously, only sporadic cases of delirium have been observed. ${ }^{6-9}$ While dizziness and restlessness have been noted in some patients in the postoperative period following the use of lorazepam or diazepam as premedicants, these symptoms were usually not severe enough to cause concern. Two of the lorazepam patients in our study were restless enough to interfere with the operation. Another patient became so confused that she attempted to climb over the siderails of her bed after return to the ward. Fortunately the nurse on the ward was able to stop her before she sustained any injury. Similar abnormal behaviour occurred after discharge from the recovery room in three of eight cases. This was especially worrisome because of the less intensive observation on the wards as compared to the recovery area.

We have no adequate explanation for the high incidence of delirium observed. When Barr, et al. ${ }^{10}$ gave lorazepam $1-2 \mathrm{mg}$ to ninety-three patients having Caesarean Section under general anaesthesia, they found only two patients with postoperative amnesia and dreaming. Lorazepam has also been given as a premedicant to patients having non-obstetrical operations under regional anaesthesia without significant mental aberrations. "A more recent study " with an extended period of observation found that the frequency of restlessness seen with lorazepam was dose related. In that study, ${ }^{11}$ restlessness occurred in 15 per cent of patients receiving lorazepam $4 \mathrm{mg}$ intravenously and three per cent of patients receiving lorazepam $2 \mathrm{mg}$ intravenously. While the dose of lorazepam used in this study was higher than in some others, ${ }^{10}$ it was within the clinically recommended range. Two of the patients developed symptoms of delirium after narcotic medication for postoperative pain relief, but the other six had not received any other medication before onset of the side effects. Use of lorazepam and morphine in combination as premedicant did not produce more restless- 
ness than lorazepam alone according to L'Armand, et $a{ }^{11}{ }^{11}$

Similar to previous studies, ${ }^{1,6.12}$ lorazepam caused greater impairment of memory than diazepam. The memory disturbance was severe enough to be distressing to two of the patients. Since events related to birth of their child are often felt to be of maximum importance to patients undergoing Caesarean Section under regional anaesthesia, the amnesia produced by lorazepam was particularly undesirable.

Neither lorazepam nor diazepam significantly reduced the number of patients who were judged to be agitated. The observer's method of assessing patients' anxiety may not have been sensitive enough to detect the difference. The high incidence of delirium also interfered with the assessment.

In conclusion, neither lorazepam nor diazepam was satisfactory as intravenous sedation for patients having Caesarean Sections under epidural anaesthesia. The large number of mental aberrations after lorazepam should preclude its use in pregnant patients at this dose. A lower dosage might produce the desired effects of sedation without delirium and amnesia but would require further evaluation.

\section{REFERENCES}

1. TAUB, H.A. \& EISENBerg, L. An evaluation of memory under regional anesthesia with IV lorazepam as a premedicant. Anesth. \& Anlg. 55:368 (1976).
2. SiNGH, A.N. \& SAXENA, B. A comparison of lorazepam, diazepam and placebo in the treatment of anxiety states. Curr. Ther. Res. 16:149 (1974).

3. OKasha, A. \& Sedek, A. A comparison of lorazepam, diazepam and placebo in anxiety states. J. Int. Med. Res. 1: 162 (1973).

4. Galloon, S., Gale, G.D. \& Lancee, W.J. Comparison of lorazepam and diazepam as premedicants. Br. J. Anaesth. 49: 1265 (1977).

5. COMER, W.H., Elliotr, H.W., Nomof, N., et al. Pharmacology of parenterally administered lorazepam in man. J. Int. Med. Res. 1: 216 (1973).

6. Blitt, C.D., Petty, W.C., Wright, W.A., et al. Clinical evaluation of injectable lorazepam as a premedicant: the effect on recall. Anesth. \& Analg. 55: 522 (1976).

7. Blitr, C.D. \& PETTY, W.C. Reversal of lorazepam delirium by physostigmine. Anesth. \& Analg. 54: 607 (1975).

8. Conner, J., Katz, R., Bellville, J., et al. Diazepam and lorazepam for intravenous surgical premedication. J. Clin. Pharmacol. 18: 285 (1978).

9. Pagano, R., Conner, J., Bellville, J., et al. Lorazepam, hyoscine, and atropine as i.v. surgical premedicants. Br. J. Anaesth. 50:471 (1978).

10. Barr, A.M., Moxon, A., Wollam, C.H.M., et al. The effect of diazepam and lorazepam on awareness during anaesthesia for caesarean section. Anaesthesia 32: 873 (1977).

11. L'ARMAND, J., VRedeVol, L.A., CONNER, J.T., et al. Lorazepam and morphine for i.v. surgical premedication. Br. J. Anaesth. 52: 1259 (1980).

12. Fragen, R.J. \& Caldwell, N. Lorazcpam premedication: lack of recall and relief of anxiety. Anesth. \& Anagl. 55: 792 (1976).

\section{RÉSUME}

On a comparé l'effet sédatif du lorazepam $0.05 \mathrm{mg} \cdot \mathrm{kg}^{-1} \mathrm{et} \mathrm{du} \mathrm{diazepam} 0.1 \mathrm{mg} \cdot \mathrm{kg}^{-1}$ sur 42 patientes subissant une césarienne sous anesthésie épidurale. Après administration de la drogue, 15 pour cent des patientes ayant reçu le diazepam et 32 pour cent le lorazepam étaient toujours agitées alors que 10 pour cent des patientes au diazepam et 36 pour cent des malades au lorazepam manifestaient des symptômes importants de délire, incluant hallucinations, confusion, agitation, pleurs sans raison et mouvements répétitifs. La perte de mémoire fut plus importante avec le lorazepam. Trente-six pour cent des patientes au diazepam ont éprouvé de la douleur au site d'injection contre aucune au lorazepam. La fréquence respiratoire, cardiaque et la tension arterielle moyenne $n$ 'ont pas changé de façon significative pour les deux groupes. La moitié des patientes qui avaient reçu du lorazepam ont éprouvé des effets secondaires désagréables assez importants pour qu'elles s'en plaignent le lendemain. Le lorazepam et le diazepam sont tous deux considérés comme non satisfaisants pour la sédation pendant la césarienne. 